\title{
ENDOGLUCANASE ACTIVITY IN LETTUCE PLANTS COLONIZED WITH THE VESICULAR-ARBUSCULAR MYCORRHIZAL FUNGUS GLOMUS FASCICULATUM
}

\author{
J. M. García-Garrido, ${ }^{1}$ M. N. Cabello, ${ }^{2}$ I. García-Romera $^{1}$ and J. A. Ocampo ${ }^{1 *}$ \\ 'Department of Microbiology, Estacion Experimental del Zaidin, Prof. Albareda 1, E-18008 Granada, \\ Spain and 'Instituto Spegazzini, 53 No. 477, 1900 La Plata, Argentina
}

(Accepted 28 April 1992)

\begin{abstract}
Summary-We studied the production of endoglucanase (EC 3.2.1.4) enzymes during the process of penetration and development of the vesicular-arbuscular (VA) mycorrhizal fungus Glomus fasciculatum in roots of lettuce (Lactuca sativa). Mycorrhizal plants showed more endoglucanase activity than non-mycorrhizal plants. Endoglucanse activity in VA-colonized plants increased at the beginning of the logarithmic stage of fungal development, and subsequently declined. The extracts from external mycelia of $G$. fasciculatum showed endoglucanase activity. Some of the endoglucanase activities detected in VA-colonized plant roots can be attributed to the VA fungus, since some of the endoglucanase proteins found in the external mycelia of $G$. fasciculatum and in mycorrhizal root extracts showed the same electrophoretic mobility. However, some of the endoglucanase activities from extracts of mycorrhizal plants had different electrophoretic mobilities than those observed in the external mycelia and in non-mycorrhizal plants.

These results suggest that endoglucanases may be involved in the process of colonization of lettuce roots by $G$. fasciculatum.
\end{abstract}

\section{INTRODUCTION}

The establishment of vesicular-arbuscular (VA) mycorrhizal symbiosis requires penetration of the host cell by fungi (Bonfante-Fasolo, 1984; Bonfante-Fasolo et al., 1990), but the mechanisms by which VA endophytes enter host tissues are still unknown. Cellulolytic enzymes, especially endoglucanases, play a fundamental role in the penetration of phytopathogenic and mutualistic microorganisms into plant cells (Coughlan and Ljungdahl, 1988; Morale et al., 1984). However, research on these enzymes in plant roots, and on their mode of action in the process of penetration and development of VA-mycorrhizal fungi, is scarce (Garcia-Romera et al., 1990). Although extracts of Glomus mosseae spores reportedly contain cellulolytic (endoglucanases) enzymes (García-Romera et al., 1990), detection of endoglucanase enzymes in VA mycorrhizal fungi is made difficult by the low levels of enzyme production (García-Romera et al., 1990); attempts to culture VA fungi in the absence of plant roots have so far been unsuccessful (Harley and Smith, 1983).

The aim of this work was to determine whether endoglucanases participate in the colonization of lettuce roots by Glomus fasciculatum.

*Author for correspondence.

\section{MATERIALS AND METHODS}

\section{Biological material and growth conditions}

Plants were grown in $300 \mathrm{ml}$ capacity open pots of soil collected from the Province of Granada, Spain. The soil of "reddish-brown" type, $\mathrm{pH} 7.6$ (for full details see García-Romera and Ocampo, 1988), was steam-sterilized and mixed with sterilized quartz sand at a proportion of $1: 1(\mathrm{~V}: \mathrm{V})$. Lettuce (Lactuca sativa cv. Romana) seeds were sown in moistened sand, and after 2 weeks seedlings were transplanted to the pots and grown under greenhouse conditions. Natural light was supplemented by Silvania incandescent and cool-white lamps, $400 \mathrm{nmol} \mathrm{m}^{-2} \mathrm{~s}^{-1}, \quad 400-700 \mathrm{~nm}$; with a $16-8 \mathrm{~h}$ light-dark cycle at $25-19^{\circ} \mathrm{C}$ and $50 \%$ r.h. Plants were watered from below using a capillary system, and fed with a nutrient solution (Hewitt, 1952) lacking phosphate for VA-inoculated plants.

The VA inoculum consisted of $5 \mathrm{~g}$ of rhizosphere soil from a maize plant pot culture of an isolate of G. fasciculatum which contained spores, mycelia and colonized root fragments. Uninoculated plants were given filtered leachings from the inoculum soil. The VA uninoculated (control) treatment consisted of soil filtrate (Whatman No. 1 filter paper) from the rhizosphere of mycorrhizal plants containing common soil microorganisms, but no propagules of $G$. fasciculatum. 
Table 1. Percentage VA root length colonization, entry points, vesicles and arbuscules in lettuce plants inoculated with $G$. fasciculatum

\begin{tabular}{llrrr}
\hline & \multicolumn{4}{c}{ Days after inoculation } \\
\cline { 2 - 5 } & 15 & \multicolumn{1}{c}{30} & \multicolumn{1}{c}{50} & \multicolumn{1}{c}{80} \\
\hline Root length colonization (\%) & $6.9 \mathrm{a}$ & $20.1 \mathrm{~b}$ & $45.1 \mathrm{c}$ & $42.4 \mathrm{c}$ \\
No. of vesicles cm $\mathrm{cm}^{-1}$ of root & $2 \mathrm{a}$ & $9.5 \mathrm{~b}$ & $57.8 \mathrm{c}$ & $38.8 \mathrm{~d}$ \\
No. of entry points $\mathrm{cm}^{-1}$ of root & $1.5 \mathrm{~b}$ & $1.8 \mathrm{~b}$ & $3.6 \mathrm{c}$ & $0.4 \mathrm{a}$ \\
Arbuscules (\%) & $1 \mathrm{a}$ & $8.7 \mathrm{~b}$ & $26.8 \mathrm{c}$ & $10.1 \mathrm{~b}$ \\
\hline
\end{tabular}

Row values sharing the same letter were not significantly different according to Duncan's multiple range test $(P=0.05)$.

Plants were harvested after $15,30,50$ or 80 days. The root system was washed and rinsed three times with sterilized distilled water. The root from each of the five replicate group of pots was divided to record (i) VA mycorrhizal colonization ( $2 \mathrm{~g}$ fresh wt) and (ii) endoglucanase activity ( $20 \mathrm{~g}$ fresh $\mathrm{wt}$ ).

External mycelia were isolated from roots of 8 week old lettuce colonized with $G$. fasciculatum. The roots were washed and rinsed gently with sterilized water, and the external mycelia collected with forceps under a dissecting microscope.

\section{Mycorrhizal measurements}

The roots were cleared and stained (Phillips and Hayman, 1970), cut in $1 \mathrm{~cm}$ segments that were mixed and repeatedly subdivided to yield random samples of 40 root segments replicate ${ }^{-1}$, which were mounted on slides and examined under a compound microscope at $\times 160$ magnification. The percentage of total root length which was colonized with VA mycorrhiza, percentage of arbuscules, number of entry points, and vesicles were measured as described by Ocampo et al. (1980).

\section{Preparation of extracts for enzyme assays}

Roots were frozen in liquid $\mathrm{N}_{2}$ and finely pulverized in a mortar. The resulting powder was homogenized in $40 \mathrm{ml}$ of $0.1 \mathrm{M}$ Tris- $\mathrm{HCl}$ buffer ( $\mathrm{pH} 7$ ) plus $13 \mathrm{~g}$ polyvinyl-polypyrrolidone (PVPP), $10 \mathrm{mM} \mathrm{MgCl}_{2}$, $10 \mathrm{~mm} \mathrm{NaHCO}, 10 \mathrm{~mm} \beta$-mercaptoethanol, $0.15 \mathrm{~mm}$ phenylmethyl sulphonyl fluoride (PMSF) and $0.3 \%$ (W/V) X-100 Triton. Sodium azide $(0.03 \%)$ was added to all solutions. The liquid was filtered through several layers of cheesecloth, centrifuged at $20,000 \mathrm{~g}$ for $15 \mathrm{~min}$, and the pellet resuspended and washed by centrifugation with the same buffer three times. The supernatant was treated with ammonium sulphate up to $80 \%$ of full saturation. The solution was kept for $5 \mathrm{~h}$ at $4{ }^{\circ} \mathrm{C}$ and centrifuged once more as described above. The supernatant was discarded, and the sediment was dissolved in a small volume of the same extractant solution and dialysed against several hundred volumes of the same diluted extractant solutions $(1: 9, \mathrm{~V}: \mathrm{V})$ for $16 \mathrm{~h}$ at $4^{\circ} \mathrm{C}$. The samples were kept frozen until use (García-Garrido et al., unpublished results).

External mycelia were frozen in liquid $\mathrm{N}_{2}$ and finely pulverized in a mortar. The resulting powder was suspended $\left(30 \mathrm{mg} \mathrm{m}^{-1}\right)$ in the same extractant solution as for roots. The suspension was briefly sonicated ( $1 \mathrm{~min}, 5$ times at $80 \mathrm{~W}$ ) and centrifuged at $20,000 \mathrm{~g}$ for $15 \mathrm{~min}$, and the pellet resuspended and sonicated again, and washed by centrifugation with the same buffer three times. The supernatant was concentrated by ultrafiltration through PM-10 membranes (AMICON Co.), and used as a crude enzyme extract.

\section{Enzyme assays}

Endoglucanase activity (EC 3.2.1.4) from the extracts of external mycelia of G. fasciculatum was detected with the agar plate method (Garcia-Romera ct al., 1990). Samples were incubated in agar (1\%) plus $0.1 \%$ carboxymethylcellulose (CMC) for $16 \mathrm{~h}$ at $30^{\circ} \mathrm{C}$. Halos of enzymatic activity were revealed by flooding plates with $0.1 \%(\mathrm{~W} / \mathrm{V})$ Congo Red for $15 \mathrm{~min}$, followed by bleaching with $1 \mathrm{M} \mathrm{NaCl}$ (Wood, 1980).

Endoglucanase activity was measured by the viscosity reducing method, with $\mathrm{CMC}$ as the substrate. Viscosity reduction was determined in a Cannon-Fenske viscosimeter $(5354 / 2)$ at $37^{\circ} \mathrm{C} .6 \mathrm{ml}$ of reaction mixture contained $5 \mathrm{ml} 0.5 \%$ enzyme substrate in $50 \mathrm{~mm}$ citrate phosphate buffer $(\mathrm{pH} \mathrm{5})$ and $1 \mathrm{ml}$ enzyme. One unit of enzyme activity was expressed on a relative activity (RA) basis as the reciprocal of time in min for $50 \%$ viscosity loss $\times 1000$ (Bateman, 1963).

Controls for all enzyme assays consisted of autoclaved enzyme extracts and buffers, and $0.03 \%$ of sodium azide was added to reaction mixtures.

\section{Polyacrylamide gel electrophoresis}

Non-denaturing linear-gradient electrophoresis of cellulolytic enzymes in polyacrylamide gels (4-12\%) amended with $0.1 \%$ CMC in $50 \mathrm{~mm}$ Tris- $-0.1 \mathrm{~m}$ glycine buffer ( $\mathrm{pH} \mathrm{8.8)}$, was based upon the method described for pectinases (Cruickshank and Wade, 1980).

Gels $16 \times 18 \mathrm{~cm} \times 25 \mathrm{~mm}$ thick were prepared using a gradient gel former (LKB). The electrode tank contained the same Tris-glycine buffer ( $\mathrm{pH} 8.8$ ) as was used in the gel. After pre-electrophoresis of the gel for $30 \mathrm{~min}$, the wells were filled with $75 \mu \mathrm{l}$ of enzyme samples, and $1 \mu 10.05 \%$ bromophenol blue in gel buffer was applied to the cathodic side. Electrophoresis was subsequently carried out at $4^{\circ} \mathrm{C}$ with a constant current of $20 \mathrm{~mA} \mathrm{gel}{ }^{-1}$ for $7 \mathrm{~h}$.

The gels were immersed in $100 \mathrm{ml}$ of $50 \mathrm{~mm}$ citratephosphate buffer (pH 5) at $37^{\circ} \mathrm{C}$ for $15 \mathrm{~h}$, after which

Table 2. Endoglucanase activity in lettuce roots uninoculated and inoculated with $G$. fasciculatum

\begin{tabular}{lcccc}
\hline & \multicolumn{4}{c}{ Days after inoculation } \\
\cline { 3 - 5 } Treatments & 15 & 30 & 50 & 80 \\
\hline & & Units $\mathrm{mg}^{-1}$ & protein \\
Uninoculated & $6.1 \mathrm{a}$ & $6.3 \mathrm{a}$ & $4.8 \mathrm{a}$ & $6.4 \mathrm{a}$ \\
VA incoulated & $13.2 \mathrm{~b}$ & $24.8 \mathrm{c}$ & $10.4 \mathrm{~b}$ & $11.6 \mathrm{~b}$ \\
\hline
\end{tabular}

Values sharing the same letter were not significantly different according to Duncan's multiple range test $(P=0.05)$. 

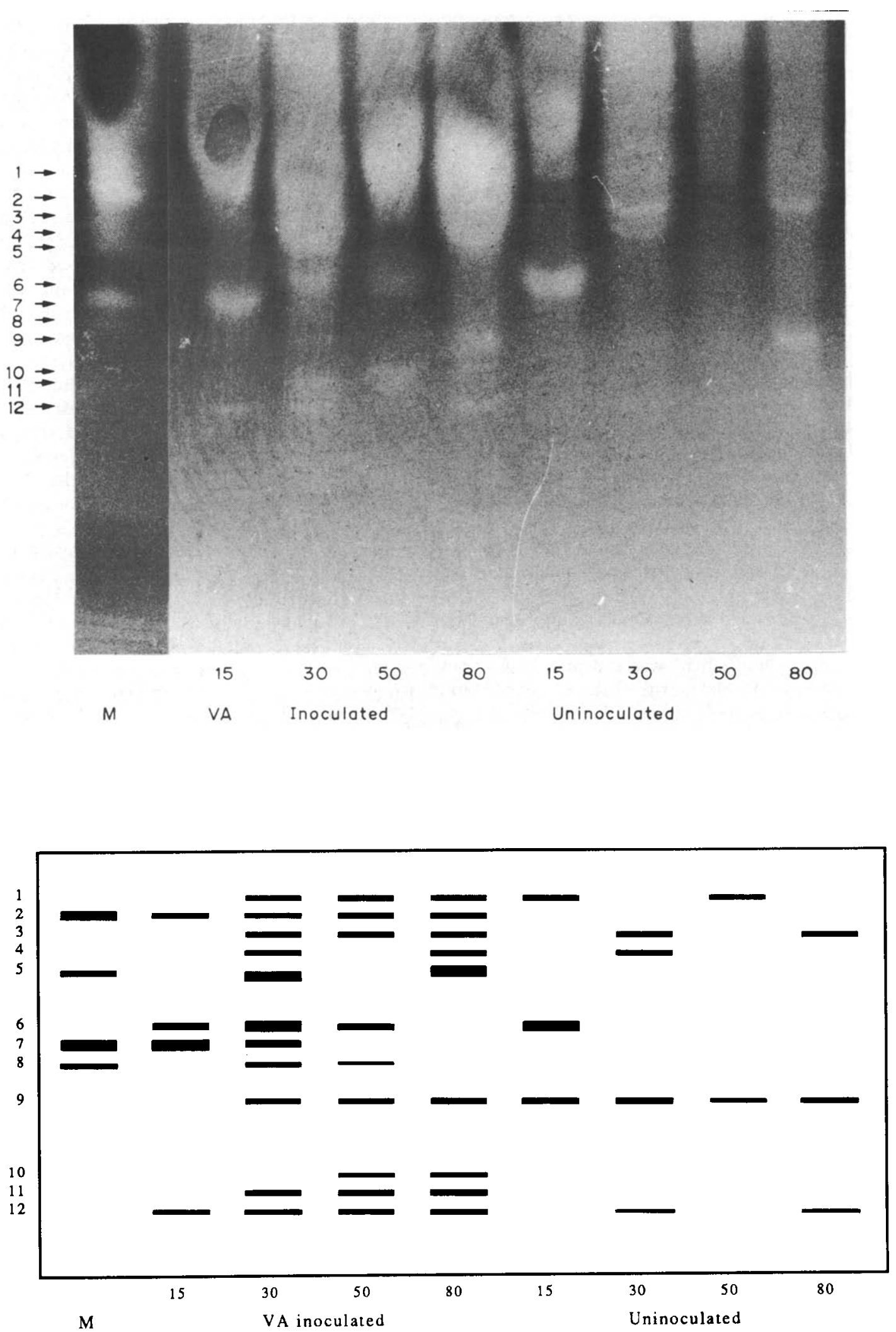

Fig. 1. Bands of endoglucanase activities (lines 1-12) in non-denaturing polyacrylamide gradient gel electrophoresis on 4-12\% acrylamide. M: extracts from external mycelium of $G$. fasciculatum; VA Inoculated: extracts from $15,30,50$ and 80 day old VA-colonized roots; uninoculated: extracts from 15 , 30,50 and 80 day old non-VA-colonized roots. The gel was stained with Congo Red and destained as described in Materials and Methods. 
they were stained with $0.1 \%$ Congo Red for $30 \mathrm{~min}$. This was followed by washing in $1 \mathrm{M} \mathrm{NaCl}$ until the bands became visible.

\section{Protein determination}

Protein was determined by the method of Lowry et al. (1951) with bovine serum albumin (Sigma) as the standard.

\section{Statistical treatment}

The results were evaluated statistically by Duncan's multiple range test.

\section{RESULIS}

The extracts of external mycelia of $G$. fasciculatum produced zones of hydrolysis in agar plates with CMC.

Microscopic observations of stained roots showed no presence of fungi in uninoculated controls (data not shown). As Table 1 shows, a typical VA colonization curve was observed in lettuce plants; 15 days after transplanting, VA colonization increased, with a peak at 50 days, at which time colonization had reached maximum levels. The numbers of entry points, vesicles and arbuscule development reached their maxima at 50 days.

Endoglucanase activity was evident in lettuce root after 15 days of plant growth (Table 2). Mycorrhizal lettuce plants showed more endoglucanase activity than non-mycorrhizal plants. The amount of this enzymatic activity in non-mycorrhizal plants was constant throughout the experiment. However, in VA-colonized roots, endoglucanase activity increased at 30 days of plant growth, and declined thereafter.

As Fig. 1 shows, the electrophoretic bands of endoglucanase activity in root extracts differed between mycorrhizal and non-mycorrhizal plants. The extracts from external mycelia of $G$. fasciculatum showed several bands of endoglucanase activity (2, 5, 7 and 8). These bands were similar to those observed in the root extracts from mycorrhizal plants, and were not apparent in extracts from non-mycorrhizal lettuce roots. The number of electrophoretic bands of endoglucanase activity was higher in mycorrhizal than in non-mycorrhizal plants at the same age. VA mycorrhizal plants showed several bands of endoglucanase activity $(1,3,4,6,9$ and 12) with similar electrophoretic mobilities to those observed in nonmycorrhizal plants. However, there were also several bands in mycorrhizal plant material (10 and 11) that were absent from non-mycorrhizal plant samples and from the external mycelia of $G$. fasciculatum.

\section{DISCUSSION}

The presence of endoglucanase activity in extracts of external mycelia of $G$. fasciculatum and $G$. mosseae spores (García-Romera et al., 1990) indicates that VA mycorrhizal fungi were able to produce this enzyme, as noted in other mutualistic microorganisms (Morales et al., 1984). Moreover, our results showed that cndoglucanase activity was higher in VAcolonized plants as compared to non-VA-colonized plants. This enzymatic activity increased in VAcolonized roots when the fungus was in its logarithmic stage of growth. The increase in fungal structures that penetrate the cell wall during the logarithmic stage of root colonization (Hayman, 1983) may explain this increase in activity. Endoglucanase activity in mycorrhizal plants decreased at the end of the assay. VA fungal development can be controlled by the plant (Harley and Smith, 1983; Anderson, 1988), and may decrease the production of endoglucanase by the fungus, as is the case with other enzymes (Spanu and Bonfante-Fasolo, 1988). The sequence of endoglucanase activity observed in the VA mycorrhizal association, and the fact that the external mycelia of $G$. fasciculatum showed endoglucanase activity, suggest that this enzyme may be involved in mycorrhizal colonization of plant roots.

Endoglucanases are present in non-VA-colonized roots (Table 2, Fig. 1) during growth and development (Byrne et al., 1975). Several electrophoretic bands of endoglucanase activity observed in VAcolonized plants had the same mobility as in the non-VA-colonized plants, however, some of these bands were present at earlier stages of plant growth in mycorrhizal plants than in non-mycorrhizal plants. This suggests that the presence of the VA fungus in the plant root activated some of the plant's cndoglucanase activitics. However, some of the endoglucanase activities found in VAcolonized roots can also be attributed to the VA fungus, since endoglucanase proteins found in the external mycelia and in the mycorrhizal root extracts showed the same electrophoretic mobility. The presence of bands different from those observed in non-mycorrhizal roots or external mycelia suggests that some of this activity may be induced by the fungus in the plant. These results indicate that endoglucanases produced by either the plant or the VA fungus may be implicated in the process of host wall degradation and cell wall mobilization during colonization as has been suggested for other symbiotic associations (Dazzo and Hubbell, 1974; Verma et al., 1982).

Acknowledgements - The authors thank Karen Shashok for grammatical correction of the text. Financial support for this study was provided by the Comision Interministerial de Ciencia y Tecnologia, Spain.

\section{REFERENCES}

Anderson A. J. (1988) Mycorrhizae-host specificity and recognition. Phytopathology 78, 375378.

Bateman D. F. (1963) Pectolytic activities of culture filtrates of Rhizoctonia solani and extract of Rhizoctonia-infected tissues of bean. Phytopathology 53, 197-204. 
Bonfante-Fasolo P. (1984) Anatomy and morphology of VA mycorrhizae. In VA Mycorrhizas (C. Ll. Powell and D. J. Bagyaraj, Eds), pp. 5-33. CRC Press, Boca-Raton.

Bonfante-Fasolo P., Vian B., Perotto S., Faccio A. and Knox J. P. (1990) Cellulose and pectin localization in roots of mycorrhizal Allium porrum: labelling continuity between host cell and interfacial material. Plantu 180, 537-547.

Burne H., Christou N. V., Pal D., Verma S. and Maclachlan G. A. (1975) Purification and characterization of two cellulases from auxin treated pea epicotyls. Journal of Biological Chemistry 250, 1013-1018.

Coughlan M. P. and Ljungdahl L. G. (1988) Comparative biochemistry of fungal and bacterial cellulolytic enzyme systems. In Biochemistry and Genetics of Cellulose Degradation (J. P. Aubert, P. Beguin and J. Millet, Eds), pp. 11-30, FEMS Symposium 43. Academic Press, London.

Cruickshank R. H. and Wade G. C. (1980) Detection of pectic enzymes in pectin-acrylamide gels. Analytical Biochemistry 107, 177-181.

Dazzo F. and Hubbell D. H. (1974) A quantitative assay of insoluble polyvinylpyrrolidone. Plant and Soil 40, 435-439.

Garcia-Romera I. and Ocampo J. A. (1988) Effect of the herbicide MCPA on VA mycorrhizal infection and growth of Pisum sativum. Zeitschrift Pflanzenernahrung Bodendenkunde 151, 225-228.

García-Romera I., García-Garrido J. M., Martinez-Molina E. and Ocampo J. A. (1990) Possible influence of hydrolytic enzymes on vesicular arbuscular mycorrhizal infection of alfalfa. Soil Biology \& Biochemistry 22, 149-152.

Harley J. L. and Smith S. E. (1983) Mycorrhizal Symbiosis. Academic Press, New York.
Hayman D. S. (1983) The physiology of vesicular-arbuscular endomycorrhizal symbiosis. Canadian Journal of Botany 61, 944-963.

Hewitt E. J. (1952) Sand water culture methods used in the study of plant nutrition. Commonwealth Agriculture Bureau, Technical Communication No. 22.

Lowry O. H., Roserbrough N. J., Farr A. L. and Randall R. J. (1951) Protein measurement with the Folinphenol reagent. Journal of Biological Chemistry 193, 265-275.

Morales V. M., Martinez-Molina E. and Hubbel D. H. (1984) Cellulase production by Rhizobium. Plant and Soil 80, 407-415.

Ocampo J. A., Martin J. and Hayman D. S. (1980) Influence of plant interactions on vesicular-arbuscular mycorrhizal infection I. Host and non-host plant grown together. New Phytologist 84, 27-35.

Phillips J. M. and Hayman D. S. (1970) Improved procedures for clearing roots and staining parasitic and vesicular-arbuscular mycorrhizal fungi for rapid assessment of infection. Transactions of the British Mycological Society 55, 158-161.

Spanu P. and Bonfante-Fasolo P. (1988) Cell-wall-bound peroxidase activity in roots of mycorrhizal Allium porrum. The New Phytologist 109, 119-124.

Verma D. P. S., Kumar V. and Maclachlan C. A. (1982) $\beta$-Glucanases in higher plants: localization, polential function, and regulation. In Cellulose and Other Natural Polymer Systems: Biogenesis, Structure and Regulation (R. M. Brown, Ed.), pp. 459-488. Plenum Press, New York.

Wood P. J. (1980) Specificity in the interaction of direct dyes with polysaccharides. Carbohydrate Research 85, 271-287. 